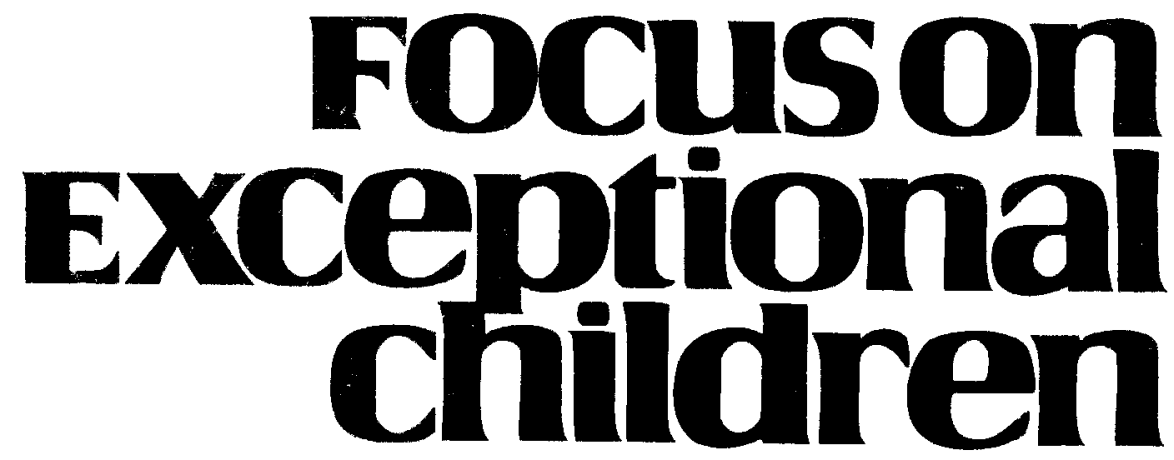

\title{
Postsecondary Settings and Transition Services for Students with Intellectual Disabilities: Models and Research
}

\author{
Debra A. Neubert and M. Sherril Moon
}

Preparing high school students for college and employment that leads to adult selfsufficiency is a daunting task for educators (Lerner \& Brand, 2006; Spence, 2007). This task becomes more complicated as technology changes rapidly, as policy makers mandate standards that all students must meet, and as schools evolve to serve more students with linguistic, academic, and social challenges. For students with intellectual disabilities (ID), their families, and the educators who provide services in the public schools, the complexity of this task increases further.

We use the term students with intellectual disabilities to include students with mental retardation, autism, traumatic brain injury, and multiple disabilities who are likely to need ongoing, individualized supports in order to participate in inclusive communities (U.S. Department of Education, 2004; U.S. Equal Employment Opportunity Commission, 2004). In some states these students receive an alternative diploma or certificate rather than a high school diploma (Johnson \& Thurlow, 2003).

Obtaining adequate support to participate in educational opportunities, attaining long-term funding for post-school services, and locating employment sites for individual students with ID require creative collaborative ventures and changes in policy (Hart, Zimbrich, \& Ghiloni, 2001; Neubert, Moon, \& Grigal, 2004; Stodden \& Whelley, 2004). Models are available allowing some students with ID to access college courses and to explore employment options that reach beyond sheltered work during their final years of public schooling (Doyle, 2003; Grigal, Neubert, \& Moon, 2001; Hall, Kleinert, \& Kearns, 2000; Hart, Zafft, \& Zimbrich, 2001; Pearman, Elliott, \& Aborn, 2004). These models can provide a blueprint for replicating similar services and for identifying issues to address through research and policy efforts.

\section{BACKGROUND}

For the past 30 years, secondary students with ID often have received instruction in segregated classes to learn functional academics/life skills and have engaged in communitybased instruction for employment, mobility, and recreation experiences (Billingsley \& Albertson, 1999). Students with ID also have increasingly accessed general education courses and extracurricular activities during their secondary years (ages 14-18) as a result

Debra A. Neubert and M. Sherril Moon are professors in the Department of Special Education at the University of Maryland at College Park. 
of legislative mandates such as the IDEA Amendments of 1997, the IDEA Improvement Act of 2004, and the No Child Left Behind Act of 2001.

Recommended practices for secondary students with ID vary and reflect the need to balance

- strategies for accessing and succeeding in general education courses,

- instruction in functional academic and communitybased skills, and

- transition services to facilitate post-school planning with adult agencies (e.g., interagency linkages, person-centered planning practices, varied employment experiences) (Inge \& Moon, 2005).

Given the difficulties associated with providing an array of practices, some have advocated that students with ID between ages 18-21 participate in alternative educational and transition services outside of the high school (Agran, Snow, \& Swaner, 1999; Certo, Pumpian, Fisher, Storey, \& Smalley, 1997; Tashie, Malloy, \& Lichtenstein, 1998). The

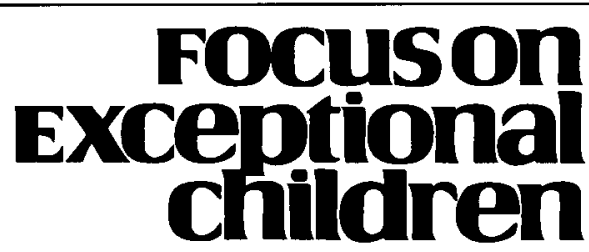

ISSN 0015-511X

FOCUS ON EXCEPTIONAL CHILDREN (USPS 203-360) is published monthly except June, July, and August as a service to teachers, special educators, curriculum specialists, administrators, and those concerned with the special education of exceptional children. This publication is annotated and indexed by the ERIC Clearinghouse on Handicapped and Gifted Children for publication in the monthly Current Index to Journals in Education (CIJE) and the quarterly index, Excep. tional Children Education Resources (ECER). The full text of Focus on Exceptional Children is also available in the electronic versions of the Education Index. It is also available in microfilm from Serials Acquisitions, National Archive Publishing Company, P.O. Box 998, Ann Arbor, MI 48106-0998. Subscription rates: individual, $\$ 42$ per year; institutions, \$56 per year. Copyright (C) 2006, Love Publishing Company. All rights reserved. Reproduction in whole or part without written permission is prohibited. Printed in the United States of America. Periodical postage is paid at Denver, Colorado. POSTMASTER: Send address changes to:

$$
\begin{gathered}
\text { Love Publishing Company } \\
\text { Executive and Editorial Office } \\
\text { P.O. Box } 22353 \\
\text { Denver, Colorado } 80222 \\
\text { Telephone (303) } 221-7333
\end{gathered}
$$

\section{EDITORIAL BOARD}

$\begin{array}{cc}\begin{array}{c}\text { Lisa Dieker } \\ \text { University of Central Florida }\end{array} & \begin{array}{c}\text { Paula Maccini } \\ \text { Marleen Pugach }\end{array} \\ \text { University of Wisconsin-Milwaukee } & \\ \text { Susan T. Warhover } & \text { Stanley F. Love } \\ \text { Editor } & \text { Publisher }\end{array}$

emphases during these years is on access to the community and planning for the future.

An additional challenge is that school personnel and families will expect students with ID to receive supported employment or day services from nonprofit community rehabilitation agencies funded by Medicaid, state developmental disabilities, or vocational rehabilitation agencies as they exit school. Therefore, the need to balance these recommended practices might seem to be less pressing. In many cases, however, students with ID face long waiting lists for comprehensive residential options or vocational services (Noyes \& Sax, 2004). Some students may not receive services, which are not entitlements, if the family or school personnel do not keep up with the paperwork and advocacy that often is required to become eligible for social security insurance, state Medicaid waivers for community-based employment and independent living options, and adult service programs. These eligibility programs are paid for primarily by state developmental disability case-management funds.

In an effort to improve post-school options for students with ID, national organizations and researchers have joined with teachers and families to advocate for the expansion of alternative education and transition services in the later years of public schooling (Grigal \& Neubert, 2004; Moon, Grigal, \& Neubert, 2001; Hart, Mele-McCarthy, Pasternack, Zimbrich, \& Parker, 2004; National Council on Disability, 2000; Patton et al. 1996; Schmidt, 2005; Smith \& Puccini, 1995). The President's Committee for People with Intellectual Disabilities (2004) recommended support for the

\footnotetext{
new emerging opportunities for students with intellectual disabilities to become involved in various transitional programs located at two-year colleges or four-year universities, or to participate in vocational education and training programs in integrated community-based settings. (p. 25)
}

These emerging opportunities are reflected in a small but growing body of literature that describes various models for students with ID, ages 18-21, in postsecondary sites (in the community or on a college campus). Our intent is to inform the field about these models so practitioners, students, and families can make informed decisions about the appropriateness of these models in the public schools. In addition, we highlight research that targets outcomes for students with ID or surveys that identify the availability of models.

\section{MODELS IN POSTSECONDARY SITES}

Although school systems have implemented models in postsecondary settings for students with ID for the past 15 years, they were not evident in the literature until recently (Gaumer, Morningstar, \& Clark, 2004; Grigal et al., 2001; Hall et al., 2000; Redd, 2004). As with other emerging areas in special education and transition services, the Office of 
Special Education Programs (OSEP) has provided federal funding for many of these efforts to document practices, provide technical assistance, and conduct research (e.g., Grigal et al., 2001; Hart, Zafft, \& Zimbrich, 2001; Neubert et al., 2004; Zafft, Hart, \& Zimbrich, 2004).

Models for providing transition services in community and college settings to students with ID who are still enrolled in public schools have been categorized as substantially separate programs, mixed programs, or inclusive individualized services (Hart et al., 2004; Stodden \& Whelley, 2004). These three models are described next, along with research that documents the existence of services and/or outcomes for students with ID ages 18-21. Although college programs (admission requirements) with support services for individuals with ID do exist after graduating from public schools (e.g., Dolynuik et al., 2002; Doyle, 2003; Hammil, 2003; Kaufman, 2006; Schmidt, 2005), they are not included in this review.

\section{Model 1: Substantially Separate Programs}

Substantially separate programs for individuals with ID have been evident at postsecondary sites since the 1970s (Neubert, Moon, Grigal, \& Redd, 2001). Historically, separate programs provided employment training, job opportunities, and segregated classes based on a "life skills" curriculum to adults with ID. Most of these programs were started and funded by nonprofit adult agencies as an alternative to day activity programs or by parents and individuals who were interested in including adults with disabilities in the community (e.g., community college campus or vocational training program).

Some school systems in the 1980s and 1990s implemented similar separate models for students with ID ages 18-21 (Gaumer et al., 2004). This was, in part, because of parents' and educators' concerns that students with ID were not being offered age-appropriate, community-based experiences (Gaumer et al., 2004; Redd, 2004). Although guidelines for developing, implementing, and evaluating various models for students with ID are available now (Baska et al., 2003; Grigal, Neubert, \& Moon, 2005), these separate programs often were started without the benefit of state/local guidelines or program evaluation data on which to base their practices (Redd, 2004).

Until now, information on the prevalence of these programs or services in school systems has been elusive. Through a national survey, Gaumer et al. (2004) recently identified 101 community-based programs in 29 states. Interestingly, 64 of the programs were established in the 1990s and 19 programs were established between 2000 and 2002. These researchers did not use the terms "separate," "mixed," and "inclusive individualized models," but they described the disability of the population served (mild/moderate, moderate/significant), the funding sources, and the operational calendar that was followed. Of the total number of programs, 48 were at postsecondary institutions, 27 at business locations, 13 at apartments or houses, and 13 were non-site-based or individualized models. Although some programs operated year-round, $73 \%$ followed the local school system calendar. Some these community-based programs were separate in terms of serving students with disabilities at a site off the high school campus, with a goal of promoting independence and access to the community before students with disabilities would leave the public schools.

In another national survey, Hart et al. (2004) identified 25 postsecondary programs for students with ID. Four of these programs were substantially separate models, had been in existence longer than the mixed or inclusive programs identified, served a larger number of students with ID in one setting, and were funded by the public school system.

Although separate programs clearly exist, we know little about the student outcomes associated with these efforts (Gaumer, Morningstar, \& Clark, 2004). In addition, we could find no research documenting student or family satisfaction or an analysis of the costs associated with this model. Research is needed to compare student outcomes served in a substantially separate model with students who remain in their high school until age 21 . In addition, we should investigate what, if any, practices in this model promote better post-school outcomes or increase quality of life for students with ID. This information then could be used to assist school system personnel, students with ID, and family members advocate for a model based on evidence-based practices (Odom et al., 2005).

At this point, the continued expansion of substantially separate models in postsecondary settings cannot be justified in light of the inclusion and transition mandates in IDEA 2004. The mixed-program model and the individualized support models promote a greater extent of inclusion in the community and foster opportunities for students with ID to interact with peers without disabilities in college and employment environments.

\section{Model 2: Mixed Programs}

Mixed programs for students with ID typically are located on community college or 4-year college or university campuses, although some are in community settings (Neubert, Moon, \& Grigal, 2002). Although this model does incorporate some separate classroom instruction, it also offers students with ID an opportunity to enroll in college classes, participate in campus social opportunities, and explore employment opportunities in the community. Students with ID in mixed programs may participate in two graduation ceremonies - one at age 18 (high school graduation) and one as they exit public schools at age 21 (graduation ceremony arranged at the college or community site) (Redd, 2004). 
The mixed-program model is implemented most frequently in local school systems (Hart et al., 2004). In an effort to determine the features and practices associated with mixed models, Grigal et al. (2001) interviewed 13 program teachers in Maryland. Mixed programs had a separate classroom or office space where a group of students and a special education teacher from the local school system spent part of the day working individually or in small groups (e.g., on functional academics, self-determination skills, transition assessment).

Practices included community-based instruction, job training, employment in enclaves and individual community sites, community service projects, interagency linkages, and parental involvement. Special educators (usually one or two per 10-15 students), transition specialists, and paraprofessionals from local school systems staffed mixed programs. Colleges or community sites donated or provided (for a fee) classroom space, equipment, and access to classes, events, and facilities. In some programs, students who qualified for Supplemental Security Income (SSI) used tuition waivers to attend community college classes (Grigal et al., 2001; Redd, 2004).

Grigal et al., 2001 identified a number of challenges with implementing mixed programs, including

- the need for more inclusive opportunities on college courses;

- access to classroom and office space for public school personnel at the college site;

- the need for flexible teacher schedules to accommodate a different calendar from that of local schools;

- the need for transportation to and from the postsecondary sites for students; and

- written procedures to dispense medication, handle disciplinary actions, and conduct IEP meetings.

Collaboration and interagency planning between schools and community rehabilitation programs and developmental disabilities services were evident in 11 of the 13 programs. Developing local interagency linkages for students with ID seemed to be a strength of this model because the teacher or transition specialist had the time to develop these linkages as a result of having a small student caseload (Neubert et al., 2004; Redd, 2004).

Descriptive information is available on the characteristics, practices, and issues associated with this model, but there is little research on student outcomes or evidencebased practices. Neubert et al. (2004) did document outcomes for 163 students with ID (ages 18-21) through a survey completed by 13 teachers in mixed programs in one state. In terms of employment or vocational training opportunities, $87 \%$ of the students participated. For those employed, the average wage was $\$ 5.91 /$ hour and the average hours worked per week was 15 . Few students received job benefits, and none were reported to receive health insurance. Only $36 \%$ of the students were enrolled in a college course, and most students audited or took non-credit courses (e.g., heath, fitness, art). Participation in college activities included Best Buddies activities, sporting events, dances, and theater events. Upon exiting school, all students were linked to an adult service agency or a community rehabilitation program, $79 \%$ qualified for Social Security (SSI) benefits, and 65\% exited with a paid job (Neubert et al., 2004).

As part of a qualitative study of one mixed program, Redd (2004) examined the perceptions of 13 students with ID and their families regarding participation and satisfaction in a mixed program on a community college campus. Even though inclusive experiences on the campus and in community employment were somewhat limited, most of the students and parents indicated satisfaction with the program and staff. All students expressed satisfaction with being on a college campus and having more freedom than in high school.

The parents reported that they were pleased that their son or daughter participated in an alternative transition experience rather than remaining in the high school building after age 18. They thought the mixed program provided opportunities for independence as their son or daughter approached adulthood and did not believe this would have been the case had their child remained at the high school until age 21 . Some parents remarked that they enjoyed the personal contact with just one teacher in the program after dealing with multiple teachers in the high school setting.

Several parents did express dissatisfaction that this program was the only option for their son or daughter after age 18 , and that a more individualized approach was not used for career planning, college-course selections, and employment options. Additional strategies to incorporate individualized career and employment options can be found in the inclusive individualized services model.

\section{Model 3: Inclusive Individualized Services}

The most recent model to emerge in the literature is an individualized approach to support students with ID during their final years of public school. In this model each student plans post-school goals with a team of individuals and then locates services or funds needed to meet the specific goals. A special educator or transition specialist serves as the case manager to coordinate services, accommodations, and supports (e.g., education or job coaches and assistive technology). Depending on the student's preferences and interests, he or she may attend college classes, a training (certificate) program, work in the community, and participate in recreational activities in the community (Hart, Zafft, \& Zimbrich, 2001). The teacher or case manager monitors each student's progress, identifies supports needed, and coordinates services 
with various institutions of higher education or agencies in the community (Hart, Zimbrich, \& Ghiloni. 2001).

This student-centered model clearly differs from separate or mixed programs in that no self-contained classes for functional skills are taught to a group of students with ID. Obviously, the case manager does not serve as a traditional teacher, because there is no separate class instruction for students with ID. Implementation of this model requires the redesign of teachers' roles to

- work with a variety of community professionals;

- identify natural and extended supports in college, work, and the community;

- monitor staff, such as educational and job coaches; and

- work flexible, 12-month work schedules (Hart, Zafft, \& Zimbrich, 2001).

Similar suggestions have been made for teachers involved in mixed or separate models (Gaumer et al., 2004; Grigal et al., 2001; Redd, 2004).

Recommended practices for this model come from descriptions of model demonstration projects and include person-centered planning, educational coaching, peer tutoring, transportation training, job coaching, mentoring, social networks, use of technology, connections to employment opportunities, and connections to agencies. This model relies heavily on cooperation and funding from state casemanagement agencies, colleges, and businesses (Hart, Zimbrich, \& Ghiloni, 2001; Stodden \& Whelley, 2004). Resources from adult and community agencies can be identified through resource mapping (Hart et al., 2004; Weir, 2004), and educational coaches and support services for students with disabilities can be identified at college sites.

In terms of research, an early qualitative study described the experiences and perception of four young men, ages 18-21, attending a community college (Page \& ChadseyRusch, 1995). This study documented practices that were closest to the inclusive individualized approach espoused by Hart, Zafft, and Zimbrich (2001). Two young men with mental retardation (MR) received case-management services from a special educator in their local school system after age 18; two young men without disabilities had graduated from the high school. All attended the same community college.

The two students without disabilities expected to graduate from the community college, and the two students with MR expected to take college classes only until they exited the school system. The students with MR took courses related to their personal interests (e.g., fitness, computers), and the other two took courses related to a major with thoughts of attending a 4-year university. Only the two students without MR believed that a college education would expand their employment opportunities, although these plans or goals were not well defined.
On a positive note, all four students reported that attending college had enhanced their social relationships. The two students with MR reported feeling more grown-up and independent as a result of their experience on the college campus. Page and Chadsey-Rusch (1995) pointed out that this study did not clearly show whether the community college campus was the most appropriate environment for the students with MR during their final years of public school and encouraged further exploration of student outcomes using this approach.

Zafft et al. (2004) compared the outcomes of 20 students with ID who used individualized supports in college and employment environments to 20 students who remained in traditional high school programs. The 40 students, ages 18-22, were from five urban school districts in Massachusetts. They were surveyed to document their participation in postsecondary education and employment, as well as the types of accommodations they received in high school and in college.

Students in the individualized support model in postsecondary education had a higher rate of employment $(100 \%)$ than the group of students who remained in the high school setting $(42.9 \%)$. In addition, $66.7 \%$ of students in the postsecondary education model worked without supports, compared to $28.6 \%$ of the students who remained in high school. Students with ID taking college classes earned $\$ 6.75 /$ hour or above at their job, while two students from the high school group did piecework, one earning $\$ .50$ per hour and the other, $\$ 4.10$ per hour. Students with ID in postsecondary education also reported using more academic accommodations in postsecondary settings compared to high school. The two groups of students were similar in terms of job benefits (for those employed) and opportunities for socialization.

Zafft et al. (2004) hypothesized that, although providing individualized supports initially may be more expensive and time-consuming during the transition years (18-22), these individuals possibly may need fewer supports as adults. Clearly, the only way to determine this is through longitudinal studies comparing both groups of individuals. As with the separate and mixed models, data concerning the costs of providing this model to students with ID outside of the high school during their final years of school is not available.

\section{WHAT LIES AHEAD}

As a result of these efforts and several federally funded projects, a number of Internet sites allow practitioners, families, and students to identify or search for services and models for students with ID throughout the country. In addition, a field-tested guide for planning, implementing, and evaluating the mixed model in Maryland has been published (Grigal et al., 2005), and Baska et al. (2003) have produced a manual on the development and operation of a communitybased transition program in Kansas. This information 
empowers families and school personnel to network, share materials, and identify strategies for collaborating with adult services, employers, and colleges. We believe that students with ID and their families also have to understand that a student's post-school goals-rather than the availability of a specific model or transition program provided by a school system-is what should guide the type of service delivery chosen for the final years of public school.

Although the three models varied in characteristics and practices, the common thread was for students with ID to receive services outside of the high school setting during their transition years (ages 18-21) (Gaumer et al., 2004; Grigal et al., 2001; Hart, Zafft, \& Zimbrich, 2001; Pearman et al., 2004; Stodden \& Whelley, 2004; Zafft et al., 2004). The descriptive studies documenting characteristics of the mixed and inclusive individualized models can serve as a starting point for those who are interested in replicating or expanding practices (e.g., Grigal et al., 2001, 2005; Hart, Zafft, \& Zimbrich, 2001; Neubert et al., 2004). The qualitative studies (e.g., Page \& Chadsey-Rusch, 1995; Redd, 2004) document issues that merit further exploration, especially student and family perceptions of services.

To persuade administrators in public schools, colleges, and adult services to work cooperatively in expanding these models, research on students' post-school outcomes and quality of life is needed. To date, only Zafft et al. (2004) have documented that students with ID who participated in the inclusive individualized model had better employment outcomes than students who remained in high school until age 22 .

\section{INFORMATION ON MODELS AND SERVICES IN POSTSECONDARY SETTINGS}

www.education.umd.edu/oco On Campus Outreach (OCO)

University of Maryland OCO provides fact sheets and articles, programs in Maryland, online training modules, and links for those who are interested in programs and services for public school students with ID (ages 18-21) at postsecondary sites (community, college, university). This site provides information to order the field-tested guide to develop, implement, and evaluate such programs and services through Pro-Ed. (See Grigal, Neubert, \& Moon, 2005)

\section{www.thinkcollege.net The New Frontier, Institute on} Disability at the University of New Hampshire

Student-related areas on this site include a searchable database for postsecondary education programs that support students with ID, wage-difference tables, application processes, and other postsecondary options. A student-run discussion board also is available. Resources for families include checklists to prepare for postsecondary situations, sample IEPs, and a Listserv for support. Professionals can gain funding strategies, sample lesson plans, and information on how to create an ID program. The resource section includes a bibliography for related publications and links to other sites.

\section{www.transitioncoalition.org Transition Coalition, University of Kansas}

Under Tools and Resources, this site offers a searchable online database of more than 100 community-based transition programs for students ages 18-21, as well as links to other transition publications. Also available for download is the manual Community Transition Program: Experiences Starting a Community-based Program for Students Aged 18-21.

www.heath.gwu.edu/Inteldisabilities.htm National Clearinghouse on Postsecondary Education for Individuals with Disabilities (HEATH), George Washington University

The HEATH website provides resource papers on how students with different types of disabilities can navigate postsecondary situations, as well as fact sheets and student accounts of their experiences when transitioning out of secondary school. Under Intellectual Disabilities there is information on programs and websites for students with ID who are interested in college experiences.

www.transitiontocollege.net Transition to College:

Information and Resources on College Options for Students with Intellectual Disabilities, TransCen Inc.

The Postsecondary Education Research Center (PERC) website provides information on program development, implementation, and evaluation, with a variety of resources, websites, and FAQ pages. An online evaluation module allows personnel to evaluate services and programs for students with ID at postsecondary sites. This site provides links to Connecticut and Maryland PERC sites.

www.communityinclusion.org/project.php?project_id=21 Institute for Community Inclusion (ICI), University of Massachusetts

This collection of fact sheets and resource papers for prospective postsecondary students includes: education and transition, policy issues, job development, job search, training events, and diversity and disability. A project dropdown menu makes available to special education professionals and employers publications about transition programs, fellowship opportunities, and support services and related links.

\section{www.rethinkhighered.com Rethink Higher Ed, Passport Program}

Passport is a degree program for unique learners (students with ID and learning disabilities) who have exited the school system and have difficulty navigating a traditional college program. Originally developed in a community college setting, this site provides information on how to develop this model program that uses a curriculum with 52 courses and culminates in an Associate in Essential Studies degree with 90 term credits. The focus is on preparing students for the workforce through academics, social and life skills, self-determination skills, and job experiences. 
Serving students with ID in postsecondary education will require new perspectives and policies in terms of providing transition services in school systems, providing initiatives for schools and adult services to share costs for services, and for providing supports, such as educational coaches and case managers, in higher education (National Council on Disability, 2003; Stodden, 2001; Stodden \& Whelley, 2004; Wolanin \& Steele, 2004; Youth Advisory Committee of the National Council on Disability, 2003). As students with ID continue to access postsecondary environments, the impact of these experiences will be felt by higher education and by community service providers who support students once they leave the school system. As the field of special education expands its vision of students with ID in college settings, we must understand the mission of higher education and work creatively to introduce supports that will ensure that students with ID will succeed in college courses and become valued members of campus communities (Noble, 1990; Stodden, 2001).

The same holds true for competitive or customized employment opportunities in communities; options to support individuals with ID in employment sites remain a pressing need in community rehabilitation agencies (Noyes \& Sax, 2004). Neubert et al. (2004) and Redd (2004) found that students with ID from mixed programs often entered community rehabilitation programs after exiting the school system, but it was unclear if this was a more restrictive environment. Issues such as this deserve attention because models in postsecondary sites aim to prepare students with ID for adult life, to share experiences with same-age peers, and to access education, work, and recreation options in the community. Families, school personnel, and adult agency personnel must find ways to ensure that adult agencies understand and continue the inclusive job, educational, residential, and recreation choices that students pursue in postsecondary sites under the auspices of school systems.

Undertaking these tasks will be easier if future research addresses questions such as the following:

- For students with ID (and their families) who are taught to navigate the college and adult service systems to obtain shared funding and support using the inclusive individualized model, do these efforts continue after the student exits public school?

- For students with ID who exit the school system in a job they chose, with appropriate supports, are they able to sustain/change employment sites, or are they eventually served in more restrictive environments (e.g., community rehabilitation program with sheltered or enclave work)?

- Are students with ID able to generalize the skill instruction (e.g., functional academic/life skills, selfdetermination skills, mobility training) provided in separate and mixed programs at postsecondary sites as they move into adult settings?

- What are the costs to a school system to provide services to students with ID in postsecondary sites compared to services within a high school until age 21 ?

- Are the post-school outcomes for students with ID who receive services at a postsecondary site different from the outcomes for students with ID who remain in the high school building until age 21?

- Can we document evidenced-based practices for serving students with ID who remain in the school system until age 21 rather than relying on expert opinion or survey research?

Ultimately, providing these models of alternative education and transition services to students with ID ages 18-21 should increase self-sufficiency and encourage choice in the adult years. As we document student outcomes and evidenced-based practices, the next challenge is to rethink how adult services are provided to individuals with ID and to create policies that support and fund changes in postsecondary education and adult service delivery systems.

\section{REFERENCES}

Agran, M., Snow, K., \& Swaner, J. (1999). Teacher perceptions of self-determination: Benefits, characteristics, and strategies. Education and Training in Mental Retardation and Developmental Disabilities, 34, 293-301.

Baska, L., Kaufman, A., Gaumer, A., Morningstar, M., Lattin, D., \& Peterson, T. (2003). The community transition program: Experiences starting a community-based program for students ages $18-21$ [Online]. Lawrence: University of Kansas, Department of Special Education. Retrieved October 14, 2004, from www.transitioncoalition.org

Billingsley, F. F., \& Albertson, L. R. (1999). Finding a future for functional skills. Journal of Association for Persons with Severe Disabilities, 24, 298-302.

Certo, N. J., Pumpian, I., Fisher, D., Storey, K., \& Smalley, K. (1997). Focusing on the point of transition: A service integration model. Education and Treatment of Children, 20, 68-84.

Dolynuik, C. A., Kamens, M. W., Corman, H., DiNardo, P. O., Tatart, R. M., \& Rockoff, J. C. (2002). Students with developmental disabilities go to college: Description of a collaborative transition project on a regular college campus. Focus on Autism \& Other Developmental Disabilities, 17, 236-241.

Doyle, M. B. (2003). "We want to go to college too": Supporting students with significant disabilities in higher education. In D. L. Ryndak \& S. Alper (Eds.), Curriculum and instruction for students with significant disabilities in inclusive settings (p. 307). Boston: Pearson Education.

Gaumer, A. S., Morningstar, M. E., \& Clark, G. M. (2004). Status of community-based transition programs: A national database. Career Development for Exceptional Individuals, 27, 131-149.

Grigal, M., \& Neubert, D. A. (2004). Parents' inschool values and postschool expectations for transition aged youth with disabilities. Career Development for Exceptional Individuals, 27, 65-85.

Grigal, M., Neubert, D. A., \& Moon, M. S. (200I). Public school programs for students with significant disabilities in post-secondary settings. Education and Training in Mental Retardation and Developmental Disabilities, 36, 244-254. 
inillluilinul

Grigal, M. Neubert. D. A.. \& Monn. M. S. (2005) Tronsition sentees fir students with significant distbilities in whese and community set-

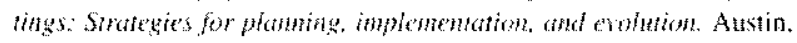
TX: Pro-Ed.

Hall. M. Kleinert. H. L., \& Kearn, F. J. 120001 . Going $\$$ college! Post secondary programs for students with moderate and wevere disabilities. Tesching Exeptional Children. $32.58-65$.

Hamill. L. B. (2003) Going to crollege: The experiences of a young wontan with Down syndrome, Mental Re harkation. 41.340-353.

Hart. D. Mele-MeCarthy, J. Pasternatk. R. Zimhrich, K. \& Parker. D. (2004). Commonity college: A pathay to success lor youth with learning. cognitive and intellectual disabilites in secondary sethings. Edtcation and Thaming in Deplommental Disabilites, 39.5467.

Hart. D. Zistt. C. \& Zimbrich. K. 20001 J. Creating access to college for all students. Jommal for hortonal Speral Needs Educatim, 23, 14-31.

Hart, D., Zimbrich, K., \& Ghiloni, C. (20)1). Interagency partnersips and funding: Individual supports for youth with signifisant disabilities as they move into postsecondary education and cmployment options.

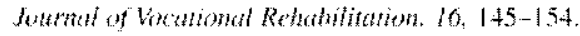

Inge. K. \& Moon, M. S. (2005), Vocational preparation and tramition. In At. Snell \& F. Brown (Eds.), Instrtetion of stitents with severe diswhilite 6 6he ed. pp. 509 609). Upper Saddle River. NJ: Merril/Prentice-Halt.

Johnson. D. R. \& Thurlow. M. L. T20031. A national study on graduation sequirements and diphoma options for youth with disubilites o Technial Report 36). Minneapolis: University of Minnesota. Nattonal Center on Educational Ontcomes. Retrieved January 24, 2004, from butp://education.umn.edu/NCEO/OntinePubs/Techulual36.hum

Kaufman. L. (2006). Jusl a normisl girl. Now York Thoses Eductutom Life, Nov 5. Section 4 A, $24-26$

Lemer. I. B. \& Brand, B. 2006 . The cullege ladder: Limking secondars und pastafeondary oduation sacress for all shodents. Washington. D. American Youlh Policy forum

Manr. M. S. Grigal, M. \& Neuben, D. A. (20)1). High school and beyond. Exceptithat Pantm. 34(1), 52w57.

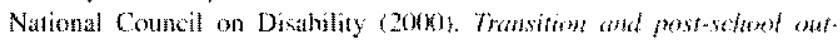

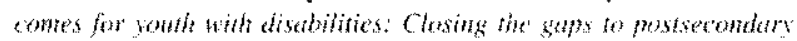
education and enslonment. Washington. DC: Author:

National Council on Disability (2003). Prople with disthilites and pust. secondory education: Pesition paper. Wasthington, DC: Author.

Neubert. D. A.. Moon. M. S., \& Grigal, M. (2002) Past-secondary education and tritnsition vervices for students $18-21$ with significant disabilitics. Forts on Excepromal Children. 34, 1-11.

Neubert, D. A., Moon. M. S. \& Grigal. M. 12004) Activities of students with significan disablities recenthy services in postsectndary sentings. Edtathon and Training in Detelopmenta Dixabilities, 39. 16-25.

Neubert. D. A. Mom, M. S. Grigal. M.. \& Redd. V. 20011 . Post-secondary eitucational pratices for individuals with mental retardation and other vigniftuant disabilities: A review at the literature. Joumat of Veational Rehablitation. 10.155-168.

Nable. G flog) An argument tor communily college ateommodations of

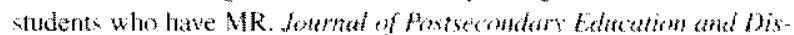
anility: 8.1530 .1570$.

Noyes. D. A., \& Sax. C. L. (2004), Changing systems for transitum: Sudents. families. and protessionals working together. Edhothon and Traming in Developmental Disabiriex. 39.3544.

Odom S. 1.., Brandinger. E. Gersen, R., Horner. R. H.. Thompson, B.. \&

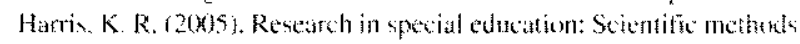
and exidence-baved pratices. Exoptional Chiden. $71,137-148$.

Page. B. \& Chadsey-Rusch. J. 1 I (9)5). The community college experience for students with and withoul disabilities: A viahle transition outcone?

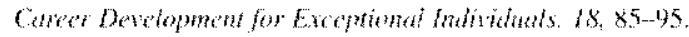

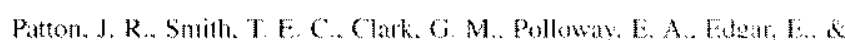
Lee, S. (1996). Individuals with mild mental retiordation: Posmes.

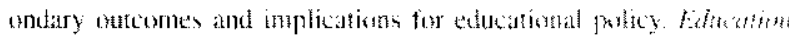

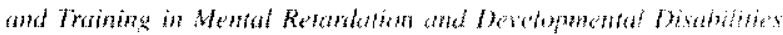
31.7585

Pearman. E. Elliol, T. \& Abom, L. 2004). Transition service mokel:

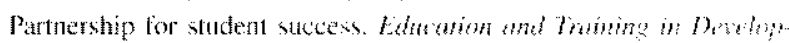
menthl Dixthilinges. 39. 26-34.

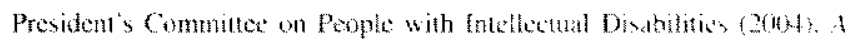

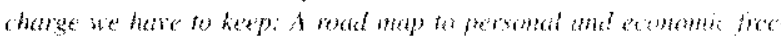

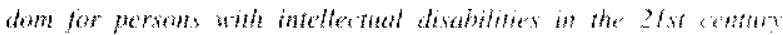
Washingtar. DC: L.S. Depurtment of Hewh and Human Services Administration for Chitdren ind Families.

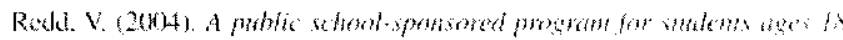

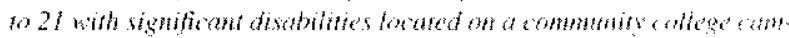

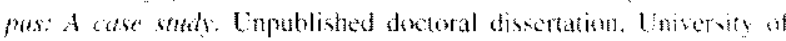
Maryland, College Path.

Schmialt. P. 20051. Students with mental retirdation atre knukhing an wh

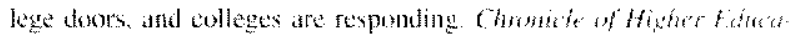
tim, $5 / 24), A 36-A 39$.

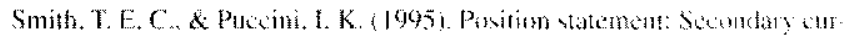

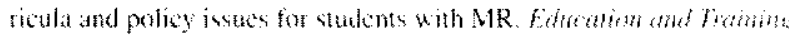

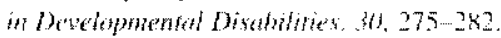

Spence. D. S. (2007). A road map to college and career reatines. Link

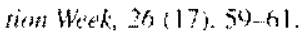

Stodden. R. A (200!). Postsecondary ducation suppors for students witis

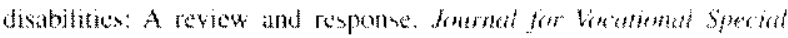
Neds Edutation. 23(2), 4-11.

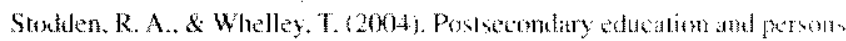

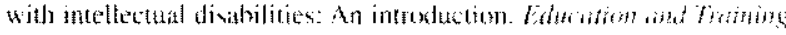
in Developmentul Disabibies. is o-15.

Tashie, C.. Malloy. J. M.. \& Lichtenstein. S. I. (1998). Transition of grado. ation'? Supporting all stutents o plan for the future. In C.J. Jongensen

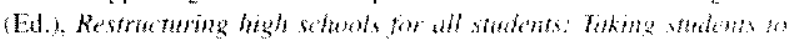
the nex level (pp. 234-259), Baltimere: Pall H. Brothes.

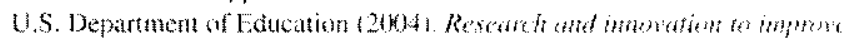

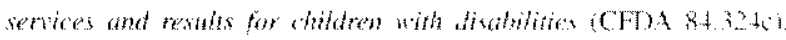
Washington. DC: Author, Offe or Special Eatuation Programs.

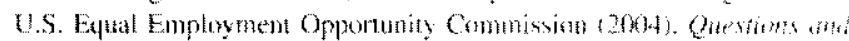

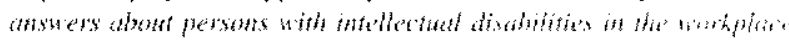

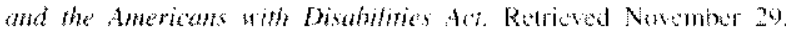
2014. from www.eenc, govfactsintelloctual disablitics, hem

Weir. C. 2004$)$. Person-entered and collaberative supporrs for college

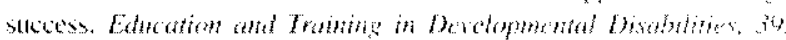
$67 \sim 73$.

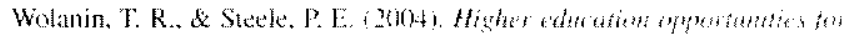

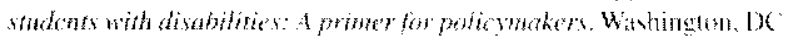
Intitute for Higher Idacition Policy

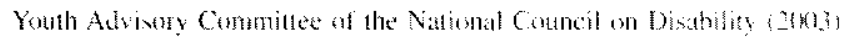

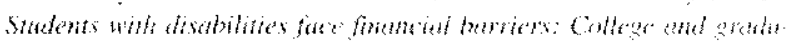

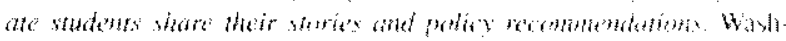
inglon. DC: Auther.

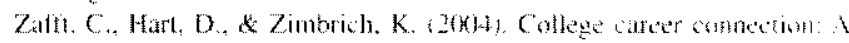

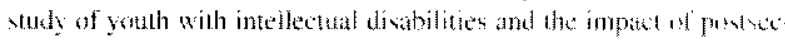

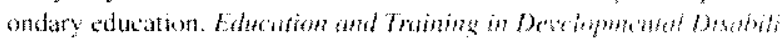
sits. 29.4553 .

Preparation of this document was supponted, in fart by the Us. Depant-

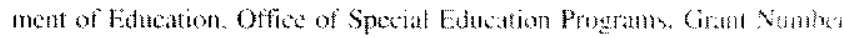
H324RO20163. The opniom in this matuscript are these of the arantes and do not nesessarily reflet those of the U.S. Departmen of Educatom. 
Copyright of Focus on Exceptional Children is the property of Love Publishing $\mathrm{Co}$. and its content may not be copied or emailed to multiple sites or posted to a listserv without the copyright holder's express written permission. However, users may print, download, or email articles for individual use. 